\title{
Trace Metal Enrichment in Sediments from Otofure and Teboga Waste Dump Sites in Benin City, Nigeria
}

\author{
Edwin O. Adaikpoh ${ }^{1} \&$ Abel N. Kaizer ${ }^{1}$ \\ ${ }^{1}$ Department of Geology, Delta State University, Abraka, Nigeria \\ Correspondence: Edwin O. Adaikpoh, Department of Geology, Delta State University, Abraka, Nigeria. Tel: \\ 234-803-727-4021. E-mail: adaikpoh_edwino@yahoo.com
}

Received: January 17, 2012 Accepted: February 6, 2012 Online Published: July 16, 2012

doi:10.5539/ijc.v4n4p14

URL: http://dx.doi.org/10.5539/ijc.v4n4p14

\begin{abstract}
Analyses of lead, copper, chromium, cadmium, nickel, zinc and manganese contents in Otofure and Teboga waste dumps in Benin City, Nigeria were carried out to determine trace metal enrichment and distribution in the soils around the dump sites and environs. Results of analyses show that trace metal concentrations in the waste dumps were greater than those from the reference background sites by magnitude concentration differences of $\mathrm{Pb}$ (18.711 mgkg $\left.{ }^{-1}\right), \mathrm{Cu}\left(12.342 \mathrm{mgkg}^{-1}\right), \mathrm{Cr}\left(0.073 \mathrm{mgkg}^{-1}\right), \mathrm{Cd}\left(0.908 \mathrm{mgkg}^{-1}\right), \mathrm{Zn}\left(104.669 \mathrm{mgkg}^{-1}\right), \mathrm{Ni}(3.522$ $\left.\mathrm{mgkg}^{-1}\right), \mathrm{Mn}\left(203.803 \mathrm{mgkg}^{-1}\right)$ in Otofure area; and Pb (3.522 $\left.\mathrm{mgkg}^{-1}\right), \mathrm{Cu}\left(10.466 \mathrm{mgkg}^{-1}\right), \mathrm{Cr}\left(0.556 \mathrm{mgkg}^{-1}\right)$, $\mathrm{Cd}\left(1.026 \mathrm{mgkg}^{-1}\right), \mathrm{Zn}\left(109.026 \mathrm{mgkg}^{-1}\right)$, Ni $\left(4.307 \mathrm{mgkg}^{-1}\right)$ and $\mathrm{Mn}\left(161.349 \mathrm{mgkg}^{-1}\right)$ in Teboga area. The calculated contamination/pollution $(\mathrm{C} / \mathrm{P})$ index values show that the dump sites were slightly polluted while the reference sites showed insignificant contamination. Analysis of enrichment factor shows that the dump sites are enriched in lead and zinc, and these decreased with distance away from the waste dump sites. The geochemical association of $\mathrm{Cr}-\mathrm{Cu}-\mathrm{Zn}$ in the soil among others shows their inclination towards anthropogenic sources. This study shows slight metal enrichment in lead and zinc content over other metals studied, but generally the average concentrations of trace metals were below international guideline values for environmental quality criteria.
\end{abstract}

Keywords: trace metals enrichment, waste dump, soil, Nigeria

\section{Introduction}

Soil (sediments) is the primary recipient of solid waste and also a reservoir of nutrients and water for plants, animals and even man (Nyle \& Ray, 1999). Thus, its contamination and degradation has far reaching effects on the entire living components of the eco-system. Millions of tons of waste materials from variety of sources (industrial, domestic and agricultural) find their way into the soil, interacting with the soil systems and changing their physical and chemical properties (Piccolo \& Mbagwu, 1997). Their accumulation has multiple effects on the usability and function of soil in the eco-system (Nielsen, 1997). Contamination of trace metals in the environment is of major interest because of their toxicity, persistence and threat to human life and the environment (Purves, 1985). Trace metal soil contamination is particularly problematic because they are not degraded in soils, as such cannot be permanently eliminated but can be locally reduced by redistribution in the eco-system or removed from circulation by immobilization (Baker, Reeves, \& Hajar, 1994; Barabara, Stephen, $\&$ William, 2002). Human activities create waste and it is the way these wastes are handled that may constitute risks to the environment and public health. Municipal solid waste heaps have become landmarks in several major cities in Nigeria obstructing motor ways and threatening to cause disease epidemics and flooding (Iwegbue, Ismirimah, Igwe, \& Williams, 2006). According to Isu (2005), 87\% of Nigerian use unsanitary methods of solid wastes disposals which constitute nuisance, ugly sight, unpleasant air and creates a breeding ground for pest and diseases.

This study therefore seeks to evaluate the distribution of trace metals in sediments around Teboga and Otofure waste dump sites and environ with the view of assessing the potential effect of the waste dumps on the area.

\subsection{Study Area}

The study area is located between latitude $6^{0} 15^{1} \mathrm{~N}$ to $6^{0} 30^{1} \mathrm{~N}$ and longitude $5^{0} 30^{1} \mathrm{E}$ to $5^{0} 45^{1} \mathrm{E}$ (Figure 1). The geology constitute part of the Niger Delta sedimentary suite described by Kogbe (1989), Adaikpoh, Kaizer and Osakwe (2005), Akpoborie, Ekakite and Adaikpoh (2000) and Shortand Stauble (1965) among others. Climatic 
conditions fall within the Rain Forest type and similar to other parts of Southern Nigeria. The climate is influenced by two prevailing air masses; the S.W. monsoon wind and the N.E. trade wind. The former prevails during the wet season and the latter during the dry season. The effects of the dry N.E trade winds are most noticeable from December to February when they usher in the dry and dusty harmattan. The annual rainfall is generally high ranging from 2000-2400 mm (Offiodile, 1992). The beginning and the end are usually marked by intense thunderstorms of short duration. The rainfall regime is double-peaked, the two periods of peak rainfall being June/July and September which are separated by a relative dry period in August. The average daily temperature of the area ranges between $30.50^{\circ} \mathrm{C}-30.90^{\circ} \mathrm{C}$ while relative humidity ranges between $60 \%-80 \%$.

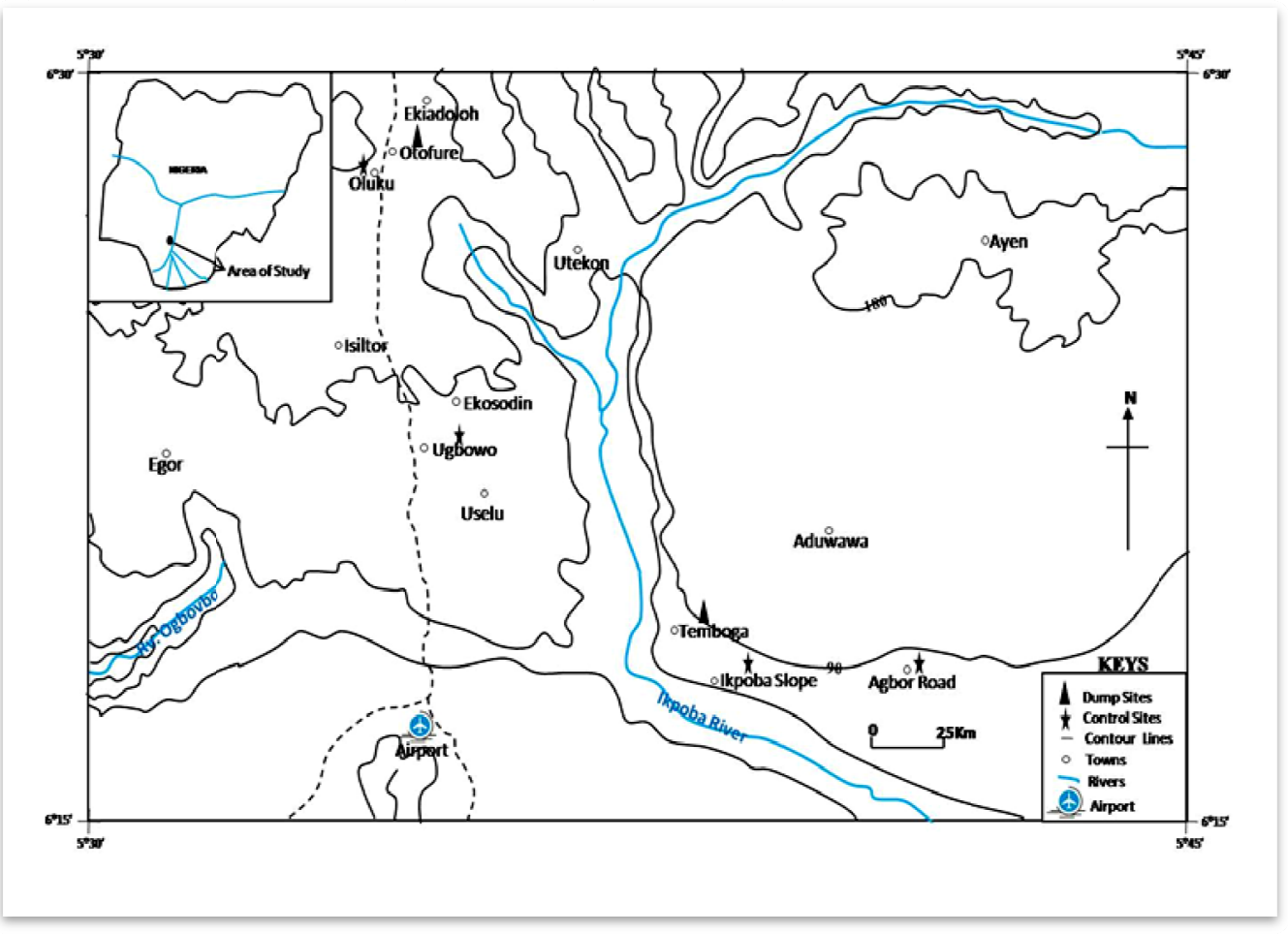

Figure 1. Map of study area

\section{Method of Study}

\subsection{Sampling Method}

Sediments samples were collected randomly due to poor accessibility, from locations around Otofure and Teboga waste dump sites at depth range of 0-30 cm, with the aid of a stainless steel iron and stored in black polythene bags for laboratory analysis.

\subsection{Analysis Procedure}

In the laboratory, the samples were first air-dried and later thoroughly homogenized using agate mortar and pestle and then subjected to analysis of their metal content using the atomic absorption spectrophotometric method. The metals determined were Zinc $(\mathrm{Zn})$, Lead $(\mathrm{Pb})$, Copper $(\mathrm{Cu})$, Chromium $(\mathrm{Cr})$, Cadmium (Cd), Nickel (Ni), Manganese (Mn). The partial extraction method was applied by weighing one gram of each sample into washed glass beakers, and the samples digested by adding $20 \mathrm{~cm}^{3}$ of aqua-region (mixture of $\mathrm{HCl}$ and $\mathrm{HNO}_{3}$ at a ratio of 3:1 and $10 \mathrm{~cm}^{3}$ of $30 \%$ of hydrogen peroxide $\left(\mathrm{H}_{2} \mathrm{O}_{2}\right)$ added. The $\mathrm{H}_{2} \mathrm{O}_{2}$ was introduced in small proportions to avoid any possible over flowing, which may lead to loss of materials (soil) from the beaker. These samples were then covered with watch glasses and heated over hot plate to about $90^{\circ} \mathrm{C}$ (near boiling point). They were then filtered hot, so as to separate the insoluble solids. These solid parts were then rinsed with hot $\mathrm{HNO}_{3}$ after which the final dilution was made with distilled de-ionized water. All the samples were then stored in plastic containers and refrigerator ready for the Atomic Absorption Spectrophotometry (AAS) method of analysis. 


\subsubsection{Enrichment Factor}

The enrichment coefficient of the metals in the soil samples were qualified by the equation described by Loska and Wiechula (2003).

$$
E_{F}=\left(C_{1} M e / C_{1 n}\right) /\left(C_{2} M e / C_{2 n}\right)
$$

Where $\mathrm{C}_{1} \mathrm{Me}=$ the examined metal content in the examined environment

$\mathrm{C}_{2} \mathrm{M}_{\mathrm{e}}=$ the examined content in the reference environment;

$\mathrm{C}_{\mathrm{ln}}=$ the reference element content in the examined environment, and

$\mathrm{C}_{2 \mathrm{n}}=$ the examined reference element content in the reference environment.

A reference element is often a conservative one, such as the most commonly used element, $\mathrm{Al}, \mathrm{Fe}, \mathrm{Mn}, \mathrm{Sc}$ and so on (Quevanviller, Lavigns, \& Cortex, 1989; Yougming, Peixuan, Junji, \& Posmentier, 2006; Nwajie \& Iwegbue, 2007). In this study, manganese was applied as a reference element because of its natural abundance. It is pertinent to note that the enrichment coefficient is a convenient measure of geochemical trends and is used for comparison between areas over time. The enrichment coefficient gives an insight into differentiating an anthropogenic source from natural origin. An enrichment factor (EF) value close to unity indicates crustal origin while values greater than 10 points to a non-crustal source (Yougming et al., 2006). Five contamination categories are recognized based on enrichment coefficient value (Sutherland, 2000; Loska \& Wiechula, 2003) (Table 1).

Table 1. Contamination Categories Based On Enrichment Factor (Ef) Values

\begin{tabular}{ll}
\hline Enrichment factor range & Significance \\
\hline $\mathrm{EF}<2$ & Deficiency to minimal enrichment \\
$\mathrm{EF}=2-5$ & Moderate enrichment \\
$\mathrm{EF}=5-20$ & Significant Enrichment \\
$\mathrm{EF}=20-40$ & Very high enrichment \\
$\mathrm{EF}>40$ & Extremely high enrichment.
\end{tabular}

Sources: (Sutherland, 2000; Loska \& Wiechula, 2003)

\subsubsection{Contamination / Pollution Index}

The contamination/pollution $(\mathrm{C} / \mathrm{P})$ index was derived by employing the contamination/pollution index as defined by Lacatusu, (2000).

$$
\mathrm{C} / \mathrm{P} \text { Index }=\text { Concentration of Metals in Soil/Target value) }
$$

The target (reference) values of metals were obtained using the standard table formulated by the Department of Petroleum Resources of Nigeria (DPR, 2002) for maximum allowed concentration of metals in soil (Table 2). A $\mathrm{C} / \mathrm{P}$ index value greater than unity (1) defines a pollution range and when the value is less than unity defines contamination ranges (Table 3). 
Table 2. Dutch Target Value, Australian, Environmental Impairment Variability and Canadian Environmental Quality Criteria

\begin{tabular}{lllllllll}
\hline Metal & \multicolumn{2}{l}{ Assessment criteria } & \multicolumn{3}{c}{ Remediation Criteria } & $\begin{array}{l}\text { DPR Target } \\
\text { values }\end{array}$ \\
& DTV & AEIL & EC & CEQC & A & R/P & C/I & \\
\hline $\mathrm{Cd}$ & 0.8 & 3 & 3.0 & 0.5 & 4 & 4 & 8 & 0.8 \\
$\mathrm{Cr}$ & 100 & 400 & - & 20 & 750 & 250 & 800 & 100 \\
$\mathrm{Cu}$ & 36 & 100 & 140 & 30 & 150 & 100 & 500 & 36 \\
$\mathrm{Ni}$ & 35 & 60 & 75 & 20 & 150 & 100 & 500 & 35 \\
$\mathrm{~Pb}$ & 85 & 60 & 300 & 25 & 375 & 500 & 100 & 85 \\
$\mathrm{Zn}$ & 140 & 20 & 300 & 60 & 600 & 500 & 1,500 & 146 \\
$\mathrm{Co}$ & 20 & - & - & - & 40 & 50 & 300 & 20 \\
$\mathrm{Mn}^{\mathrm{d}}$ & & & & & & & & 437 \\
$\mathrm{Fe}^{\mathrm{d}}$ & & & & & & & & 5000
\end{tabular}

${ }^{a}$ Dtv Dutch Target Value, AEIL Australian ecological investigation level EC European Communities. (EQC Canadian environment quality criteria).

${ }^{\mathrm{b}}$ A Agricultural purposes, R/P residential/Parkland, C/I Industrial/Commercial.

${ }^{\mathrm{c}}$ DPR Department of Petroleum Resources target values.

${ }^{\mathrm{d}}$ Derived from selected global average (Alloway, 2005).

Table 3. Significance of interval of contamination/pollution $(\mathrm{C} / \mathrm{P})$ index value

\begin{tabular}{ll}
\hline C/P index & Significance \\
\hline$<0.1$ & Very slight contamination \\
$0.10-0.25$ & Slight contamination \\
$0.26-0.50$ & Moderate contamination \\
$0.51-0.75$ & Severe contamination \\
$0.76-1.00$ & Very severe contamination \\
$1.1-2.0$ & Slight pollution \\
$2.1-4.0$ & Moderate pollution \\
$4.1-8.0$ & Severe pollution \\
$8.1-16.0$ & Very severe pollution \\
$>16$ & Excessive pollution \\
\hline
\end{tabular}

Source: Lacatusu (2000).

\section{Results and Discussion}

\subsection{Result}

The results of the geochemical analysis on soil samples obtained from the study area are presented in Table 4-11.

\subsection{Discussion}

The total mean concentration in $\mathrm{gkg}^{-1}$ and standard deviation of trace metals in soil samples from the study area and reference sites shows that manganese has the highest mean concentration of $139.401 \mathrm{mgkg}^{-1}$. and chromium with the lowest of $0.484 \mathrm{mgkg}^{-1}$. The mean concentrations of trace metals in the samples decrease in the following order of magnitude in $\mathrm{mgkg}^{-1}, \mathrm{Mn}(139.401)>\mathrm{Zn}(54.008)>\mathrm{Pb}(24.814)>\mathrm{Cu}(5.702)>\mathrm{Ni}$ $(3.009)>\mathrm{Cd}(0.48)>\mathrm{Cr}(0.219)$ (Table 6). From the range Table 7, trace metals in the samples shows lead $(\mathrm{Pb})$ $<0.001-118.36 \mathrm{mgkg}^{-1}$, Copper $(\mathrm{Cu})<0.001-1.584 \mathrm{mgkg}^{-1}$, Zinc (Zn) $0.34-120.113 \mathrm{mgkg}^{-1}$, Cadmium (Cd) 
$<0.001-1.584 \mathrm{mgkg}^{-1}$, Zinc (Zn) $0.34-120.113 \mathrm{mgkg}^{-1}$, nickel (Ni) $0.32-7.632 \mathrm{mgkg}^{-1}$ and manganese (Mn) $38.20-294.302 \mathrm{mgkg}^{-1}$. It is observed that trace metal concentration in the study area is greater than those of the reference site by magnitude concentration difference of $\mathrm{Pb}\left(18.711 \mathrm{mgkg}^{-1}\right) \mathrm{Cu}\left(12.342 \mathrm{mgkg}^{-1}\right), \mathrm{Cr}(0.073$ $\left.\mathrm{mgkg}^{-1}\right) \mathrm{Cd}\left(0.908 \mathrm{mgkg}^{-1}\right), \mathrm{Zn}\left(104.669 \mathrm{mgkg}^{-1}\right), \mathrm{Ni}\left(3.522 \mathrm{mgkg}^{-1}\right), \mathrm{Mn}\left(203.803 \mathrm{mgkg}^{-1}\right)$ in Otofure area and $\mathrm{Pb}\left(80.316 \mathrm{mgkg}^{-1}\right), \mathrm{Cu}\left(10.446 \mathrm{mgkg}^{-1}\right), \mathrm{Cr}\left(0.556 \mathrm{mgkg}^{-1}\right), \mathrm{Cd}\left(102 \mathrm{mgkg}^{-1}\right), \mathrm{Zn}\left(109.026 \mathrm{mgkg}^{-1}\right), \mathrm{Ni}$ (4.307 $\left.\mathrm{mgkg}^{-1}\right)$, Mn (161.349 $\left.\mathrm{mgkg}^{-1}\right)$ Teboga area (Table 7).

\subsubsection{Contamination/Pollution Index}

Assessment of the soil sample for trace metal pollution based on absolute metal content value provides inadequate information on the significance of the value obtained with the intrinsic soil feature and how the value is related to the maximum allowable limits for each. The presence of one metal can significantly affect the impact that another has on organisms (Iwegbue et al., 2010). This effect can be synergistic, additive and antagonistic (Eisler, 1993). Based on the limitation of (Iwegbue, Nwajei, \& Overah, 2010) method, the Lacatusu (2000) method was used for this study. Based on these, the contamination/pollution index was calculated as the ratio between metals effectively measured by chemical analysis to the reference value (Table 3). Generally, standard used such as the Department of Petroleum Resources (2002) target value and the conversion formula (Lacatusu, 2000) for the C/P index vary from one country to another based on the chosen criteria. The calculated $\mathrm{C} / \mathrm{P}$ index values were interpreted according to the scheme provided in Table 3.

\subsubsection{Enrichment Factor (EFs)}

Enrichment factor (EFs) can also be effective tools to differentiate a natural origin from an anthropogenic source. The calculated enrichment (EF) shows that $\mathrm{Ni}, \mathrm{Cr}$ and $\mathrm{Mn}$ have enrichment factors close to unity, $\mathrm{Pb}$ and $\mathrm{Zn}$ were greater than 10 , while $\mathrm{Cu}$ and $\mathrm{Cd}$ are lacking (Table 8). Observed concentrations of $\mathrm{Ni}, \mathrm{Cr}$ and $\mathrm{Mn}$ are attributed to natural sources while $\mathrm{Pb}$ and $\mathrm{Zn}$ are due to anthropogenic sources (Yougming et al., 2006). Mean EFs decreased in this order $\mathrm{Pb}>\mathrm{Zn}>\mathrm{Co}>\mathrm{Mn}>\mathrm{Ni}>\mathrm{Cd}=\mathrm{Cu}$ which can also be seen as the degree of the overall contamination by trace metal in soil samples from the dump sites. Most sites have enrichment factor values in the deficiency to minimal enrichment domain except for $\mathrm{Pb}$ and $\mathrm{Zn}$ that have enrichment factor values in the extremely high enrichment category (Table 2). This implies that the dump sites are enriched in $\mathrm{Pb}$ and $\mathrm{Zn}$. Trace metal concentration at the study area decreased with distance away from the waste dumps (Table 5).

Correlation matrix of the trace metal data indicates strong positive correlations $\mathrm{r}^{2}>0.50$ ) between $\mathrm{Pb}$ with $\mathrm{Cr}-$ $\mathrm{Ni}, \mathrm{Cu}$ with $\mathrm{Cd}-\mathrm{Zn}-\mathrm{Ni}-\mathrm{Mn}, \mathrm{Cr}$ with $\mathrm{Ni}$, Cd with $\mathrm{Zn}-\mathrm{Ni}-\mathrm{Mn}, \mathrm{Zn}$ with $\mathrm{Ni}-\mathrm{Mn}$ and Ni with Mn. A weak positive correlation $\left(\mathrm{r}^{2} \leq 0.5\right)$ was seen in $\mathrm{Pb}$ with $\mathrm{Cu}-\mathrm{Cd}-\mathrm{Zn}, \mathrm{Cu}$ with $\mathrm{Cr}, \mathrm{Cr}$ with $\mathrm{Cd}-\mathrm{Zn}$. The significant positive correlation within these metals reveal the common source of contamination from refuse dumped on the site which sinks into the soil of the study area.

Also indicated by same correlation matrix of the trace metal data is a strong positive correlation $\left(\mathrm{r}^{2}>0.50\right)$ between $\mathrm{Pb}$ and $\mathrm{Cu}-\mathrm{Ni}-\mathrm{Mn}, \mathrm{Cu}$ and $\mathrm{Zn}, \mathrm{Cr}$ and $\mathrm{Ni}-\mathrm{Mn}, \mathrm{Zn}$ and $\mathrm{Ni}, \mathrm{Ni}$ and $\mathrm{Mn}$ while weak positive correlation $\left(\mathrm{r}^{2} \leq 0.50\right)$ occurs between $\mathrm{Pb}$ and $\mathrm{Cu}, \mathrm{Cu}$ and $\mathrm{Ni}-\mathrm{Mn}, \mathrm{Cr}$ and $\mathrm{Zn}$ with a very negative correlation between $\mathrm{Cu}$ and $\mathrm{Mn}$ (Table 12). The significant positive correlation within the metals also reveal their inclination toward anthropogenic sources but, the concentration of trace metal at the reference sites were minute compared to the waste dumps. In general, for both correlations, the geochemical association of $\mathrm{Cr}-\mathrm{Cu}-\mathrm{Zn}$ in the soil shows that these metals are deposited from anthropogenic sources, since there is no known geogenic source which can contribute to this type of association in the study area.

From the result of analysis, high levels of metals are observed in the dump sites with manganese $\left(294.302 / 203.634 \mathrm{mgkg}^{-1}\right)$, lead $\left(118.36 \mathrm{mgkg}^{-1}\right)$, zinc $\left(115.201 / 103.750 \mathrm{mgkg}^{-1}\right)$, and manganese $\left(257.765 / 167.053 \mathrm{mgkg}^{-1}\right)$. The levels of metals obtained in this study were compared with both domestic and International guidelines (Table 3). The Dutch "target values" based on natural soil levels and on negligible risk concentration used in the Netherlands for soil protection (Lame \& Leenaer, 1998) are similar to the Department of Petroleum resources targets values in Nigeria. However, other International guidelines for metals in soils include Canadian Soil Quality Criteria (CCME 1991), the Australian Ecological Investigation levels (EIL) and maximum concentration of toxic metal in soils permitted under the European community regulation (Kabata-Pendians \& Pendias, 1992) are presented in Table 3 for comparison. It is pertinent to note that guidelines for re- development of contaminated land were not available for comparison. Hence, the Canadian soil quality criterion was used. These criteria are based on level above which remedial action is necessary before such lands can be used for agricultural, residential and/or industrial purpose. 


\subsubsection{Lead}

The species of lead $\mathrm{Pb}$ vary considerably with soil type; it is mainly associated with clay minerals, $\mathrm{Mn}$ oxides, $\mathrm{Fe}$ and $\mathrm{Al}$ hydroxides and organic matter. In some soil types, $\mathrm{Pb}$ may be highly concentrated in calcium carbonate particles or in phosphate concentration and a baseline $\mathrm{Pb}$ value for surface soil (Gowd, Reddy, \& Govil, 2010). The average content of $\mathrm{Pb}$ in the soil samples is $24.814 \mathrm{mgkg}^{-1}$ and ranges from $<0.001$ to $118.36 \mathrm{mgkg}^{-1}$ (Figure 2). The concentration magnitude of $\mathrm{Pb}$ shows that the soils is practically uncontaminated with $\mathrm{Pb}$. Lead value for surface soil on the global scale has been estimated to be $25 \mathrm{mg} / \mathrm{kg}$ and levels above this suggest an anthropogenic influence (Kabata-Pendias, 2004). The EF obtained for $\mathrm{Pb}$ ranges from 8.879-275-831 which indicate that the soils in the study area show significantly-extremely high enrichment. Similarly, the C/P index ranges from $0.0007-1.392 \mathrm{mgkg}^{-1}$ and indicates that the sample ranges from very slight contamination to slight polution.

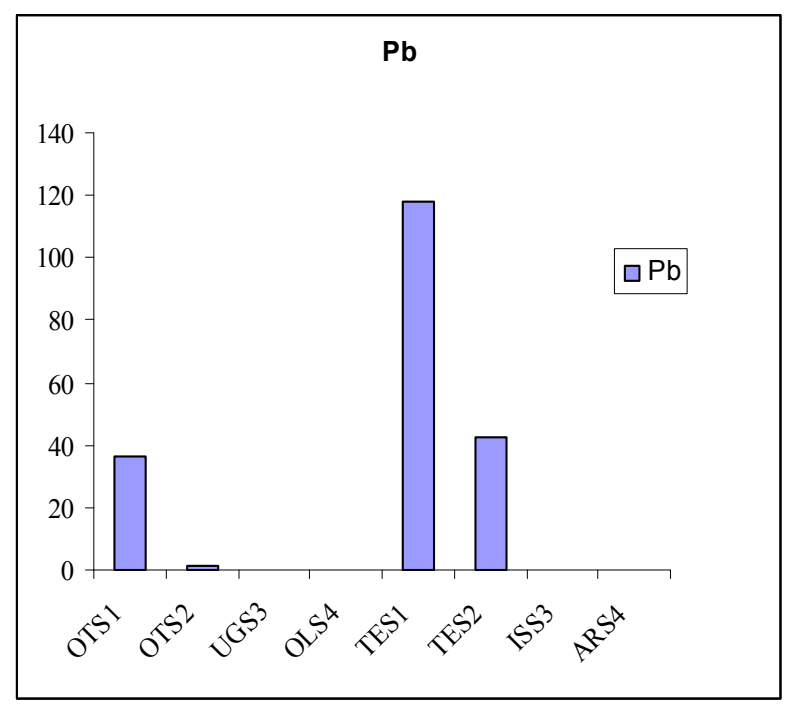

Figure 2. Chart showing concentration of Lead in the different sample locations

Lead concentration spanning between 47.15 and $155.07 \mathrm{mgkg}^{-1}$ (Oyelola \& Babatunde, 2008), and 1.41 - 109.9 $\mathrm{mg} / \mathrm{kg}$ (Iwegbue et al., 2010), have been reported in soils of municipal waste dumps and other contaminated sites in Nigeria. The concentration found in the Otofure and Temboga area is similar for the range reported by Iwegbue et al. (2010) but was relatively higher than levels observed by Nwajei, Iwegbue and Okafor (2007).

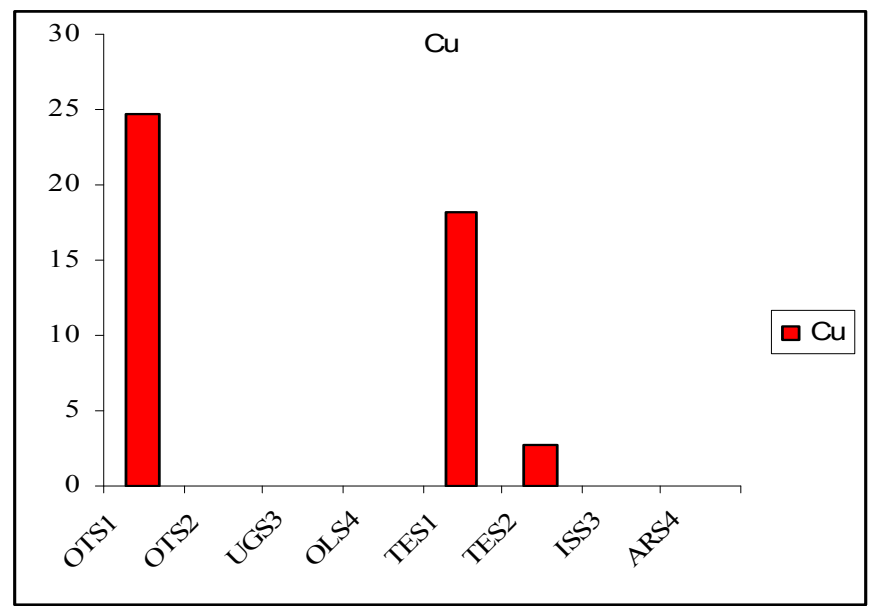

Figure 3. Concentration of Copper in the different sample locations 


\subsubsection{Copper}

The normal threshold value prescribed in soil is $30 \mathrm{mgkg}^{-1}$ and copper normally accumulates in the surface horizons, a phenomenon explained by the bioaccumulation of the metal and recent anthropogenic sources (Kabata-Pendias, 2004). The average copper content in the soil examined was $5.702 \mathrm{mg} / \mathrm{kg}$ and its concentration ranges were $<0.001-24.684$ (Figure 4). The EF obtained was nil pointing towards "Deficiency to minimal enrichment" in the soil. The C/P index obtained spanned from $<0.001-0.686$ indicating very slight contamination to severe contamination, hence from its low average concentration compared with CEQC standard, copper is of low concentration in the soil.

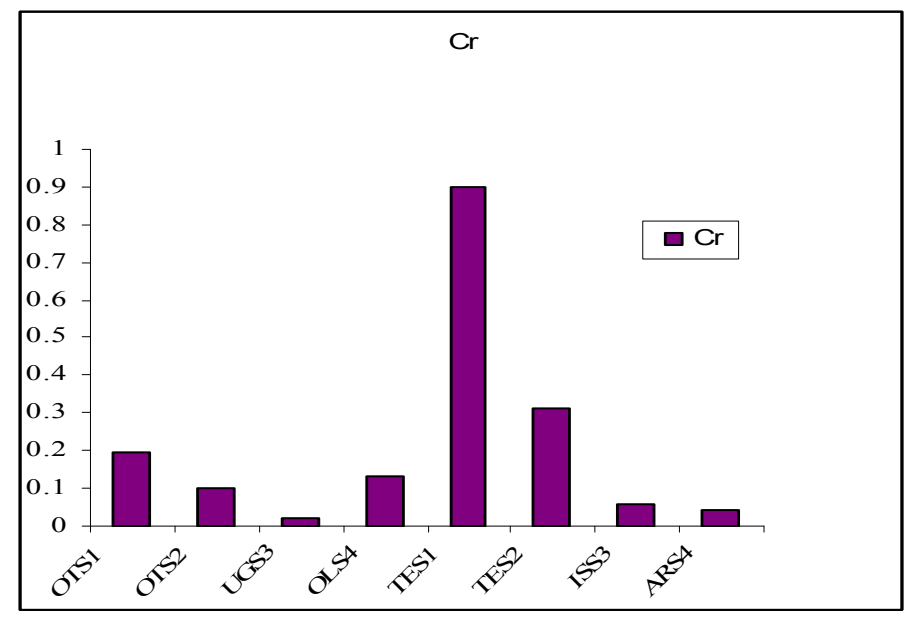

Figure 4. Chart showing concentration of Chromium in the different sample locations

\subsubsection{Chromium}

Chromium is a low mobility element, especially under moderately oxidizing and reducing conditions and near -neutral $\mathrm{pH}$ values. $\mathrm{Cr}^{+6}$ absorption decreased with increasing $\mathrm{pH}$ and $\mathrm{Cr}^{+3}$ adsorption increases with increasing $\mathrm{pH}$. On the other hand, $\mathrm{Cr}^{+6}$ are toxic for biological systems. The average concentration is $0.219 \mathrm{mgkg}^{-1}$ and ranges from $0.02-0.897 \mathrm{mgkg}^{-1}$ in the soil samples collected (Figure 4). The EF revealed that the samples fell into the class of deficiency to minimal enrichment-moderate enrichment (0.302-3.554). The contamination/pollution index obtained for $\mathrm{Cr}$ ranged from 0.0016-0.002 indicative of a very slight contamination. The concentration of Chromium observed in the present day study is lower compared to value reported by Oyelola and Babatunde (2008).

\subsubsection{Cadmium}

The average Cadmium content in the soil examined is $0.484 \mathrm{mg} / \mathrm{kg}^{-1}$ and ranges from $<0.001-1.584 \mathrm{mgkg}^{-1}$ in the soil samples (Figure 5). The normal threshold value prescribed in soil for Cadmium is $0.5 \mathrm{mg} / \mathrm{kg}^{-1}$ (CCME, 1991). The EF is zero indicating deficiency to minimal enrichment of $\mathrm{Cd}$ in the soil similarly the $\mathrm{C} / \mathrm{P}$ index ranges from $<0.001-1.98$ pointing at very slight contamination to slight contamination. The $\mathrm{Cd}$ concentration observed in this present study is similar to the concentration reported by Njoku and Ayoku (2007) in Owerri Southeastern Nigeria. 


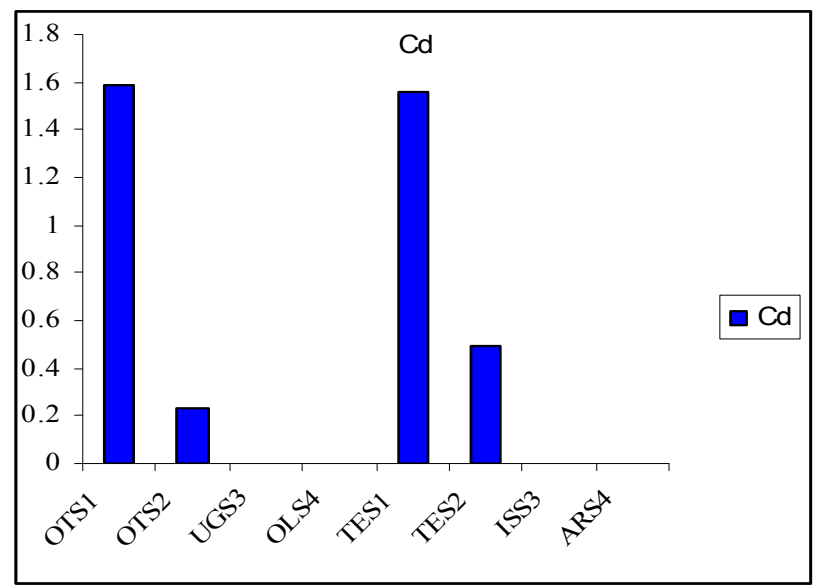

Figure 5. Chart showing concentration of Cadmium in the different sample locations

\subsubsection{Zinc}

Zinc belongs to a group of trace metals, which are essential for the growth of humans, animals and plants and are potentially dangerous for the biosphere when present in high concentrations. The main sources of pollution are industries and the use of liquid manure, composted materials and agrochemicals such as fertilizers and pesticides in agriculture (Gowd, et al., 2010). The average zinc concentration in the dump sites is $54.008 \mathrm{mgkg}^{-1}$ (range 0.34-120.113 $\mathrm{mgkg}^{-1}$ (Figure 6). The EF indicates a range of 25.601-70.469 (Extremely high enrichment) and the $\mathrm{C} / \mathrm{P}$ index ranges from $0.00233-0.789$ which points at slight contamination to very severe contamination. From CCME, the threshold value for Zinc $\left(60 \mathrm{mgkg}^{-1}\right)$ compared with present study indicates low enrichment. The result from the Otofure and Teboga dump site were higher than levels from soils in northern Nigeria as reported by Eliagwu, Ajibola and Folaranmi (2007).

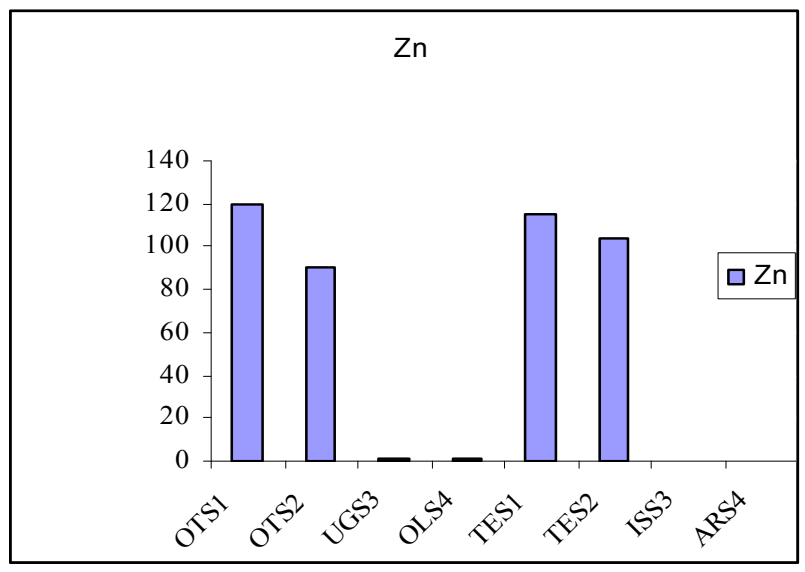

Figure 6. Chart showing concentration of Zinc in the different sample locations

\subsubsection{Nickel}

The Nickel content in dump site samples ranges from $0.32-7.632 \mathrm{mgkg}^{-1}$ (Figure 7), with an average of 2.578 $\mathrm{mgkg}^{-1}$. Nickel in soil is usually present in the organically bound form, which under acidic and neutral conditions increases its mobility and bio availability (Kabata - Pendias \& Pendias 1999). The EF value ranges from 0.594-1.305 which falls under the deficiency to minimal enrichment category and the $\mathrm{C} / \mathrm{P}$ index ranging from 0.0914-0.218 (very slight contamination-slight contamination). 


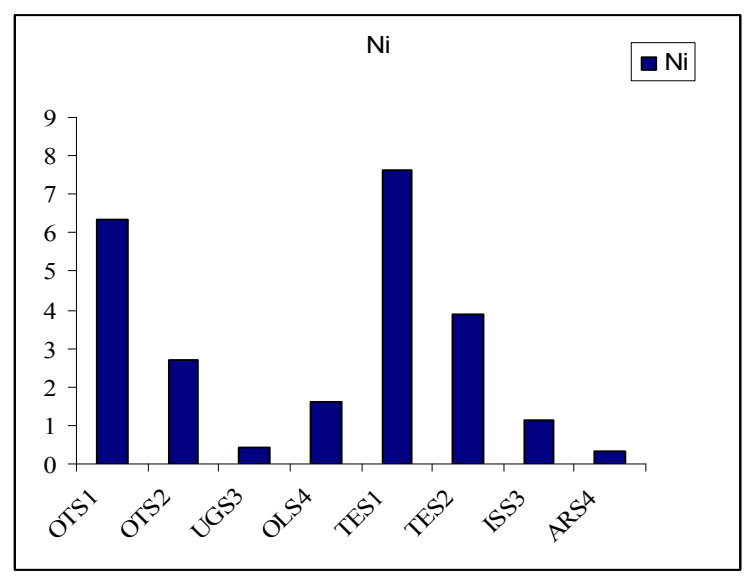

Figure 7. Chart showing concentration of Nickel in the different sample locations

\subsubsection{Manganese}

The average concentration of Manganese in the soils sample is $139.401 \mathrm{mgkg}^{-1}$ and ranges from $38.20-294.302$ $\mathrm{mg} / \mathrm{kg}^{-1}$ (Figure 8). It has an EF of unity although indicating crustal origin and falls into the category of deficiency to minimal enrichment. The $\mathrm{C} / \mathrm{P}$ value ranges from 0.0943 to 0.674 whose significance is very slight contamination severe contamination.

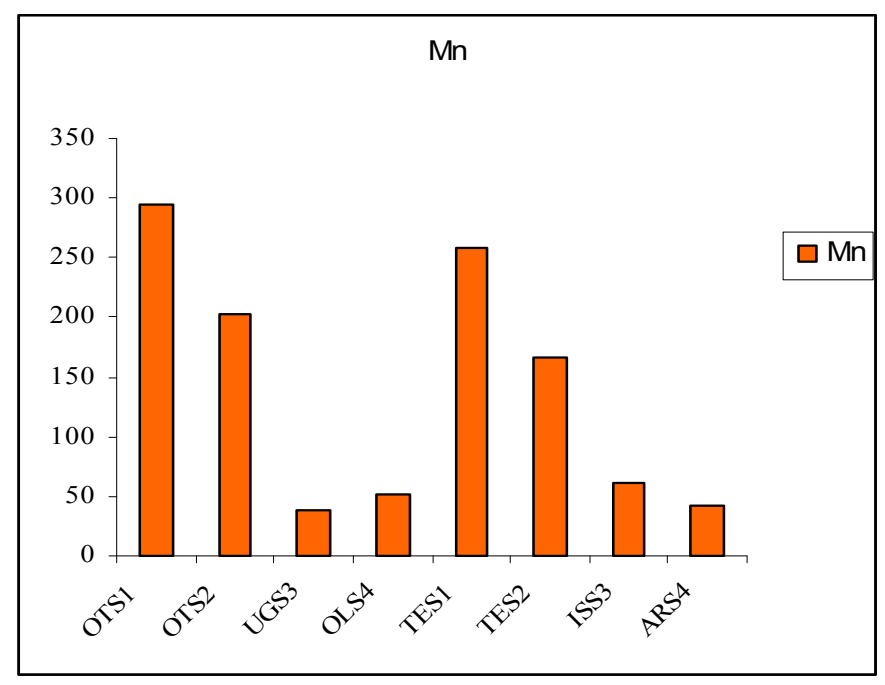

Figure 8. Chart showing concentration of Manganese in the different sample locations

Generally although the study shows slight metal enrichment in $\mathrm{Pb}$ and $\mathrm{Zn}$ content over other metal studied, the average concentration of trace metals were below international guide values (CEQC). 
Table 4. Concentration in $\mathrm{mgkg}^{-1}$ of trace metals in soil samples from the studied sites (Otofure and Teboga) and reference sites (Oluku, Ugbowo, Ikpoba slope and Agbor road)

\begin{tabular}{|c|c|c|c|c|c|c|c|}
\hline Sample Code & $\mathrm{Pb}$ & $\mathrm{Cu}$ & $\mathrm{Cr}$ & $\mathrm{Cd}$ & $\mathrm{Zn}$ & $\mathrm{Ni}$ & $\mathrm{Mn}$ \\
\hline OTS1 $(\mathrm{N}=13)$ & 36.281 & 24.684 & 0.194 & 1.584 & 120.113 & 6.361 & 294.302 \\
\hline OTS2 $(\mathrm{N}=10)$ & 1.201 & $<0.001$ & 0.102 & 0.232 & 90.665 & 2.703 & 203.634 \\
\hline \multirow[t]{2}{*}{ MEAN $(Z 1) \mathrm{N}=23$} & $37.482 \pm$ & $24.684 \pm$ & $0.296 \pm$ & $1.816 \pm$ & $210.778 \pm$ & $9.064 \pm$ & $497.936 \pm$ \\
\hline & 4.50 & 6.50 & 0.86 & 0.68 & 25.34 & 7.10 & 51.35 \\
\hline UG3S3 $(\mathrm{N}=9)$ & $<0.001$ & $<0.001$ & 0.02 & $<0.001$ & 0.61 & 0.42 & 38.20 \\
\hline OLS4 $(\mathrm{N}=11)$ & 0.06 & $<0.001$ & 0.13 & $<0.001$ & 0.83 & 1.60 & 58.13 \\
\hline MEAN (Z2) & $0.06 \pm$ & $<0.001 \pm$ & $0.15 \pm$ & $<0.001 \pm$ & $1.44 \pm$ & $2.02 \pm$ & $96.33 \pm$ \\
\hline $\mathrm{N}=20$ & 3.15 & 0.00 & 0.08 & 0.00 & 0.37 & 0.15 & 5.44 \\
\hline TES1 $(\mathrm{N}=12)$ & 118.36 & 18.204 & 0.897 & 1.560 & 115.201 & 7.632 & 257.765 \\
\hline TES2 $(\mathrm{N}=10)$ & 42.442 & 2.728 & 0.314 & 0.492 & 103.750 & 3.901 & 167.053 \\
\hline MEAN (Z3) & $160.802 \pm$ & $20.932 \pm$ & $1.211 \pm$ & $2.052 \pm$ & $218.951 \pm$ & $11.533 \pm$ & $424.818 \pm$ \\
\hline $\mathrm{N}=22$ & 21.17 & 5.61 & 0.28 & 0.34 & 19.72 & 1.42 & 12.07 \\
\hline ISS3 $(\mathrm{N}=10)$ & 0.13 & $<0.001$ & 0.06 & $<0.001$ & 0.56 & 1.14 & 60.90 \\
\hline ARS4 $(\mathrm{N}=8)$ & 0.04 & $<0.001$ & 0.04 & $<0.001$ & 0.34 & 0.32 & 41.22 \\
\hline MEAN $(\mathrm{Z} 4) \mathrm{N}=18$ & $\begin{array}{l}0.17 \pm 0.2 \\
0\end{array}$ & $\begin{array}{l}<0.001 \pm 0 \\
.0\end{array}$ & $\begin{array}{l}0.10 \pm 0.0 \\
6\end{array}$ & $\begin{array}{l}<0.000 .0 \\
0\end{array}$ & $0.90 \pm 0.60$ & $\begin{array}{l}1.46 \pm 0.8 \\
2\end{array}$ & $\begin{array}{l}102.12 \pm 8.1 \\
5\end{array}$ \\
\hline TOTAL SUM & 198.514 & 45.616 & 1.757 & 3.868 & 432.069 & 24.077 & 1115.204 \\
\hline TOTAL AVE. & 24.814 & 5.702 & 0.219 & 0.484 & 54.008 & 3.009 & 139.401 \\
\hline$\sigma$ Standard Deviation & 110.46 & 9.270 & 0.271 & 0.649 & 50.618 & 2.578 & 97.823 \\
\hline
\end{tabular}

OTS1 = Otofure Waste dumps 1, OTS2 = Otofure Waste dumps 2, UG S3 = Ugbowo, OL S4= Oluku, TES1 = Teboga Dump Site 1, TES2 = Teboga Dump Site 2, ISS3 = Ikpoba Slope and ARS4 = Agbor Road

Table 5. Range and total average concentration in $\mathrm{mkg}^{-1}$ of soil samples

\begin{tabular}{lll}
\hline Trace metal & Range $\mathrm{mgkg}^{-1}(\mathrm{~N}=83)$ & Total average concentration $(\mathrm{N}=83)$ \\
\hline $\mathrm{Pb}$ & $<0.001-118.36$ & $24.814 \pm 110.46$ \\
$\mathrm{Cu}$ & $<0.001-24.684$ & $5.702+9.270$ \\
$\mathrm{Cr}$ & $0.02-0.897$ & $0.219 \pm 0.271$ \\
$\mathrm{Cd}$ & $<0.001-1.584$ & $0.484 \pm 0.649$ \\
$\mathrm{Zn}$ & $0.34-120.113$ & $54.008 \pm 50.618$ \\
$\mathrm{Ni}$ & $0.32-7.632$ & $3.009 \pm 2.578$ \\
$\mathrm{Mn}$ & $38.20-294.302$ & $139.401 \pm 97.323$ \\
\hline
\end{tabular}


Table 6. Observed difference in concentration magnitude between waste dump samples and reference background site

\begin{tabular}{llllllll}
\hline Sample site & $\mathrm{Pb}$ & $\mathrm{Cu}$ & $\mathrm{Cr}$ & $\mathrm{Cd}$ & $\mathrm{Zn}$ & $\mathrm{Ni}$ & $\mathrm{Mn}$ \\
\hline $\begin{array}{l}\text { Otofure dump site } \\
\text { (N=23) }\end{array}$ & 18.741 & 12.342 & 0.148 & 0.908 & 105.389 & 4.532 & 248.968 \\
Ugbowo/ & 0.03 & - & 0.075 & - & 0.72 & 1.01 & 45.165 \\
$\begin{array}{l}\text { Oluku (N=20) } \\
\text { Difference (A) }\end{array}$ & 18.711 & 12.342 & 0.073 & 0.908 & 104.669 & 3.522 & 203.803 \\
$\begin{array}{l}\text { Teboga Waste } \\
\text { Dump (N=22) }\end{array}$ & 80.401 & 10.466 & 0.606 & 1.026 & 109.476 & 5.767 & 212.409 \\
$\begin{array}{l}\text { Ikpoba slope and } \\
\text { Agbor } 0.085\end{array}$ & - & 0.05 & - & 0.45 & 1.46 & 51.06 \\
(N=18) road & & & & & & & \\
Difference (B) & 80.316 & 10.466 & 0.556 & 1.026 & 109.026 & 4.307 & 161.349 \\
\hline
\end{tabular}

Table 7. Enrichment Factor of trace metal in soil samples from Otofure and Teboga waste dump sites.

\begin{tabular}{lcccc}
\hline Metal & OTOFURE I $(\mathrm{N}=13)$ & $\begin{array}{c}\text { OTOFURE 2 } \\
(\mathrm{N}=10)\end{array}$ & $\begin{array}{l}\text { TEMBOGA I } \\
(\mathrm{N}=12)\end{array}$ & $\begin{array}{c}\text { TEMBOGA 2 } \\
(\mathrm{N}=10)\end{array}$ \\
\hline $\mathrm{Pb}$ & 185.595 & 8.879 & 275.831 & 152.617 \\
$\mathrm{Cu}$ & - & - & - & - \\
$\mathrm{Cr}$ & 0.397 & 0.302 & 3.554 & 1.919 \\
$\mathrm{Cd}$ & - & - & - & - \\
$\mathrm{Zn}$ & 25.601 & 27.928 & 50.711 & 70.469 \\
$\mathrm{Ni}$ & 0.967 & 0.594 & 1.305 & 0.816 \\
$\mathrm{Mn}$ & 1.000 & 1.000 & 1.000 & 1.000 \\
\hline
\end{tabular}

Table 8. Comparison of Contamination/Pollution Index of metals in soils from the waste dumps and reference sites

\begin{tabular}{lllllllll}
\hline Metals & OTS1 & OTS2 & UGS3 & OLS4 & TES2 & TES2 & ISS3 & ARS4 \\
& $\mathrm{N}=13$ & $\mathrm{~N}=10$ & $\mathrm{~N}=9$ & $\mathrm{~N}=11$ & $\mathrm{~N}=12$ & $\mathrm{~N}=10$ & $\mathrm{~N}=10$ & $\mathrm{~N}=8$ \\
\hline $\mathrm{Pb}$ & 0.424 & 0.014 & - & 0.0007 & 1.392 & 0.499 & 0.0015 & 0.00047 \\
$\mathrm{Cu}$ & 0.686 & - & - & - & 0.506 & 0.075 & - & - \\
$\mathrm{Cr}$ & 0.002 & 0.001 & 0.0002 & 0.0013 & 0.009 & 0.003 & 0.0016 & 0.0004 \\
$\mathrm{Cd}$ & 1.98 & 0.29 & - & - & 1.95 & 0.615 & - & - \\
$\mathrm{Zn}$ & 0.823 & 0.621 & 0.00418 & 0.0057 & 0.789 & 0.711 & 0.00383 & 0.00233 \\
$\mathrm{Ni}$ & 0.181 & 0.077 & 0.012 & 0.046 & 0.218 & 0.111 & 0.0326 & 0.00914 \\
$\mathrm{Mn}$ & 0.674 & 0.466 & 0.087 & 0.119 & 0.589 & 0.382 & 0.139 & 0.0943
\end{tabular}

OTS1 = Otofure Waste dumps 1, OTS2 = Otofure Waste dumps 2, UG S3 = Ugbowo, OL S4= Oluku, TES1 = Teboga Dump Site 1, TES2 = Teboga Dump Site 2, ISS3 = Ikpoba Slope and ARS4 = Agbor Road. 
Table 9. The significance of interval of contamination/pollution $(\mathrm{C} / \mathrm{P})$ index ranges for the study area and reference sites are shown below

\begin{tabular}{ll}
\hline Sample Sites & Significance \\
\hline Otofure Waste dumps 1 (OTS1) & Very slight contamination - slight pollution \\
Otofure Waste dumps 2 (OTS2) & Very slight contamination - severe contamination \\
Ugbowo (UG S3) & Very slight contamination \\
Oluku (OL S4) & Very slight Contamination- Slight Contamination \\
Teboga Dump Site 1 (TES1) & Very Slight contamination - slight pollution \\
Teboga Dump Site 2 (TES1) & Very slight contamination - very serve contamination \\
Ikpoba Slope ( ISS3) & Very slight contamination - slight contamination \\
Agbor Road (ARS4) & Very slight contamination \\
\hline
\end{tabular}

Table 10. Correlation of trace metals in soil samples from otofure and teboga waste dump

\begin{tabular}{llllllll}
\hline & $\mathrm{Pb}$ & $\mathrm{Cu}$ & $\mathrm{Cr}$ & $\mathrm{Cd}$ & $\mathrm{Zn}$ & $\mathrm{Ni}$ & $\mathrm{Mn}$ \\
$\mathrm{Pb}$ & 1.000 & & & & & & \\
$\mathrm{Cu}$ & 0.400 & 1.000 & & & & & \\
$\mathrm{Cr}$ & 1.000 & 0.400 & 1.000 & & & & \\
$\mathrm{Cd}$ & 0.400 & 1.000 & 0.400 & 1.000 & & & \\
$\mathrm{Zn}$ & 0.400 & 1.000 & 0.400 & 1.000 & 1.000 & & \\
$\mathrm{Ni}$ & 0.800 & 0.800 & 0.800 & 0.800 & 0.800 & 1.000 & \\
$\mathrm{Mn}$ & 0.000 & 0.800 & 0.000 & 0.800 & 0.800 & 0.600 & 1.000 \\
\hline
\end{tabular}

Table 11. Correlation of trace metal in soil from reference background sites

\begin{tabular}{llllllll}
\hline & $\mathrm{Pb}$ & $\mathrm{Cu}$ & $\mathrm{Cr}$ & $\mathrm{Cd}$ & $\mathrm{Zn}$ & $\mathrm{Ni}$ & $\mathrm{Mn}$ \\
\hline $\mathrm{Pb}$ & 1.000 & & & & & & \\
$\mathrm{Cu}$ & .447 & 1.000 & & & & & \\
$\mathrm{Cr}$ & .800 & .000 & 1.000 & & & & \\
$\mathrm{Cd}$ & - & - & - & - & & & \\
$\mathrm{Zn}$ & .000 & .894 & .400 & - & 1.000 & & \\
$\mathrm{Ni}$ & .600 & .447 & .800 & - & .800 & 1.000 & \\
$\mathrm{Mn}$ & 1.000 & -.447 & .800 & - & .000 & 0.600 & 1.000 \\
\hline
\end{tabular}

\section{Conclusion}

From results of geochemical analysis, the Otofure and Teboga wastes dumps site show evidence of slight contamination although the study shows slight metals enrichment in $\mathrm{Pb}$ and $\mathrm{Zn}$ content over other metals studied. Risk assessment based upon soil quality guidelines limits proves that the soil does not have serious health risk with respect to humans. However, a proper and modern engineered disposal method should be adopted to reduce the concentration of the metal load in the waste materials before final disposal. Such method may include reducing the waste volume by pyrolysis and subsequently treating the metal waste chemically to remove the metal content, before final disposal by burial in a land fill site.

\section{References}

Adaikpoh, E. O., Kaizer, A. N., \& Osakwe, S. A. (2005). Distribution of heavy metals in Subsurface soils in Abraka and Environ, Southwest Nigeria. J. African scientist, 6(1), 29-33.

Akpoborie, I. E., Ekakite, O. A., \& Adaikpoh, E. O. (2000). The Quality of Groundwater from Wells in part of 
the Western Niger Delta. J. NAFAK, 5, 72-79.

Allen, J. R. L. (1965). Late Quartenary Niger Delta and Adjacent areas. Sedimentary environments and Lithosfacies. Bull. AAPG, 49, 547-600.

Alloway, B. J. (2005). Bioavailability of trace metal in soil. In: Selinus, O., Centeno, J. A., Finkleman, R. B., Fuge, R., Lindh, U. and Smedly, P. (eds). Essentials of medical geology. Impacts of the natural environment and public health. London: Elsevier Academic Press, 347-372.

Asseez, O. L. (1986). Review of the stratigraphy, sedimenta tion and structure of the Niger-Delta. In: Kogbe, C. A. (Eds ). Geology of Nigeria. Rockview, (Nig) Ltd. Jos, 311-324.

Baker, A. J. M., Reeves, R. D., \& Hajar, A. S. M, (1996). Heavy metal accumulation and tolerance in British population of the metallphyte Thlapsi Caerulescens J. and C. Presl (Brassicaceae). New Phytol, 127, 61-68. http://dx.doi.org/10.1111/j.1469-8137.1994.tb04259.x

Barabara, F., Stephen, K., \& William, W., (2002). Speciation and character of heavy metals contaminate soil using computer controlled scan electron microscope. Environ. Forensic, 3(2), 131-143. DOI: http://dx.doi.org/10.1080/15275920216256.

Burke, K. (1972). Longshore drift, submarine canyons and submarine fans in development of Niger delta. Bull. $A A P G, 56,1975-1983$.

Canadian Council of Ministers of the Environment (CCME), (1991). Interim Canadian environment quality criteria for contaminated sites. Report CCME EPC-C534, Winnipeg, Manitoba.

Department of Petroleum Resources (2002). Environmental guidelines and Standards for the petroleum industries in Nigeria Department of Petroleum Resources, Abuja, Nigeria: Ministry of Petroleum and Mineral Resources.

Eisler, R. (1993). Zinc Hazards to Fish, Wild life and Invertebrates; a synoptic review. U.S. Fish Wildl. Serv. Biol. Rep., 85(1.10), 90.

Eliagwu, S. E., Ajibola, V. O., \& Folaranmi, F. M. (2007). Studies on the impact of municipal waste dumps on secondary soil and air quality of two Cities in Northern Nigeria. J. Applied Sci., 7(3), 421-425. http://dx.doi.org/10.3923/jas.2007.421.425

Gowd, S. S., Reddy, R. M., \& Govil P. K. (2010). Assessment of heavy metal Contamination in Soils at Jajmau (Kanpur) and Unnao Industrial areas, of the Ganga plain, Uttar Pradesh. India J. Hazard Mater., 174, 113-121. http://dx.doi.org/10.1016/j.jhazmat.2009.09.024

Isu, B. A. (2005). The pains of waste. A paper presented at the workshop organized by committee on Vital Environmental Resources for Teachers/Students, Eghosa Anglican Grammar School, Benin City, 1-6.

Iwegbue, C. M. A., Ismirimah, N. O., Igwe, C., \& William, E. S. (2006). Characteristic levels of heavy metal in soil profiles of automobile mechanic waste dumps in Nigeria. Environmentalist, 26, 131-137. http://dx.doi.org/10.1007/s10669-006-7482-0

Iwegbue, C. M. A., Nwajei, G. W., \& Overah, C. L. (2010). Determination of trace metal Concentration in soil profiles of municipal waste dumps in Nigeria. Environ Geochem Health, 32, 415-430. http://dx.doi.org/10.1007/s10653-010-9285-y

Kabata-Pendias, A., \& Pendia, H. (1992). Trace elements in soil and plants. (2nd ed.). Boca Raton, Fl.: CRC Press.

Kabata-Pendias, A. (2004). Soil-Plant transfer of heavy metals-An Environmental Issue. Geoderma, 122. 143-149. DOI: http://dx.doi.org/10.1016/j.geoderma.2004.01.004

Kalu, C., Modugu, W. W., \& Ubochi, I. (2009). Evaluation of solid waste management policy in Benin Metropolis, Edo State Nigeria. J. African Scientist, 10. 1-7.

Kogbe, C. A. (1989). Geology of Nigeria ( $2^{\text {nd }}$ Edn). Rock View Ltd. Jos. 311-325.

Kulke, H. (1995). Nigeria, In Kulke, H. (ed), Regional Petroleum Geology of the World. Part II. African, American, Australia and Antactica: Berlin, Gebruder Borntrager. 143-172.

Lacatusu, R. (2000). Appraising Levels of Soil Contamination and pollution with Heavy Metals, European Soil Bureau Research Report Number 4.

Lame, F. J. P., \& Leenaer, H. (1998). Target values and background levels in the Netherlands: How to define 
good Soil quality. In Contaminated Soil 1998. Preedings of the $6^{\text {th }}$ international KZK/TNO Conference on Contaminated soil, 17-21 May 1998, Edinburgh, London. United Kingdom: Thomas Telford Publishing, 2, 783-784.

Lehner, P., \& De Ruiter, P. A. C. (1977). Structural history of Atlantic Margin of Africa. Bull. AAPG, 61, 961-981.

Loska, K., \& Wiechula, D. (2003). Application of Principle Component analysis for the estimation of source of heavy metal contamination in surface sediments from the Rybnik reservoir. Chemistry, 51, 123-733.

Murat, R. C. (1972). Stratigraphy and Palaeogeography of the Cretaceous and Lower Tertiary in Southern Nigeria. In Dessavagie, T. F. S and Whitman. A. J. (Ed.), African Geology, Ibadan, Nigeria: Ibadan University Press, 251-276.

Neilsen, F. H. (1997). Trace Elements. In Macrae R., Robinson, R.K and Sadler, K.J. (Ed.). Ency. Fd. Sci Fd. Tech. Nutri. London: Academic Press, 283.

Nwajei, G. E., Iwegbue, C. M. A., \& Okafor, M. I. (2007). Heavy Metals in Surface Soils Under Waste Dumps from Onitsha, Nigeria. J. Biol. Sc., 7(2), 405-408. http://dx.doi.org/10.3923/jbs.2007.405.408

Nyle, I. B., \& Ray, R. N. (1999). The Nature and Properties of Soils. 12th Edn. United States of America. 734-785.

Oyelola, O. T., \& Babatunde, A. I. (2008). Effect of Municipal Solid Wastes on the Levels of Heavy Metals in Olusosun Dumpsite soil, Lagos State, Nigeria. International J. Phys. and Appl. Sci., 2 (1), 17-21.

Piccolo, A., \& Mbagwu, J. S. C, (1997). Exogenous Humic Substances as Conditions for the Rehabilitation of Degraded Soils. Agro Foods Industry Hi Tech, 21-28.

Purves, D. (1985). Trace-element Contamination of Environmental Amsterdam. Retrieved from Elsevier.

Quevanviller, P., Lavigns, R., \& Cortex, L. (1989). Impact of industrial drainage wastes on the heavy metal distribution in the drainage basin and estuary of the Sado River, Portugal. Env. Pollution, 59, 267-286. http://dx.doi.org/10.1016/0269-7491(89)90155-3

Short, K. C., \& Stauble, A. J. (1967). Outline of Geology of Niger Delta. Bull. AAPG, 54 (5), 761-779.

Sutherland, R. A. (2000). Bed-sediments associated trace metal in urban stream Oahu, Hawaii. Env. Geol, 39, 361- 627. http://dx.doi.org/10.1007/s002540050473

Weber, K. J. (1971). Sedimentological Aspects of Oil fields in the Niger Delta. Geology on Mijnbouw, 50, 559-576.

Yongming, H., Peixuan, D., Junji, C., \& Posmentier, E. S. (2006). Multivariate Analysis of Heavy Metals Contamination in urban dusts of Xi'an, Central China. Sci. Total Environ., 355, 176-186. http://dx.doi.org/10.1016/j.scitotenv.2005.02.026 